\title{
PENINGKATAN KETERAMPILAN MENULIS TEKS BIOGRAFI \\ DENGAN MODEL PEMBELAJARAN INKUIRI PADA SISWA \\ KELAS X SMA PARULIAN 1 MEDAN \\ TAHUN PEMBELAJARAN 2018/2019 \\ Dian Syahfitri \\ Dedi Syahputra Silalahi \\ Pendidikan Bahasa dan Sastra Indonesia \\ Universitas Prima Indonesia \\ dssdedi@gmail.com
}

\begin{abstract}
ABSTRAK
Penelitian ini bertujuan untuk meningkatkan kemampuan menulis teks biografi dengan menggunakan model pembelajaran inkuiri siswa kelas X SMA Parulian 1 Medan Tahun Pelajaran 2018/2019. Penelitian ini adalah penelitian tindakan kelas, yang terdiri dari dua siklus yaitu siklus I dan siklus II. Subjek penelitian siswa kelas X SMA Parulian 1 Medan. Pelaksanaan penelitian ini dilakukan berdasarkan permasalahan yang ada pada pembelajaran menulis teks biografi siswa masih tergolong rendah. Model yang digunakan dalam penelitian ini adalah kualitatif deskriptif dengan pendekatan tindakan kelas yang mendeskripsikan kemampuan menulis teks biografi pada siswa secara klasikal dan kemampuan menulis teks biografi melalui model pembelajaran inkuiri. Berdasarkan hasil penelitian menunjukkan bahwa dengan menggunakan model pembelajaran inkuiri dapat meningkatkan kemampuan menulis teks biografi. Terbukti dengan adanya peningkatan hasil belajar siswa dari siklus I ke siklus II. Hasil tes siklus I di peroleh nilai rata-rata 68 , dan tes siklus II meningkat dengan nilai rata-rata 82 dan telah mencapai KKM $\leq 70$. Dilihat dari persentase ketuntasan klasikal siswa pada siklus I $48 \%$ meningkat pada siklus II $88 \%$. Penelitian ini dapat disimpulkan bahwa dengan menggunakan model pembelajaran inkuiri dapat meningkatkan kemampuan menulis teks biografi siswa kelas X SMA Parulian 1 Medan.
\end{abstract}

Kata Kunci: Teks Biografi, Model Pembelajaran Inkuiri, Penelitian Tindakan

Kelas

\section{PENDAHULUAN}

\begin{tabular}{lrll}
\multicolumn{2}{c}{ Keterampilan menulis } & dikuasai oleh siswa. Hal ini \\
merupakan salah satu aspek & dikarenakan pada kegiatan menulis \\
berbahasa yang penting dan perlu & membutuhkan proses berpikir yang
\end{tabular}


baik dalam mengungkapkan suatu pikiran dalam bentuk tulisan. Keterampilan berbahasa memiliki empat komponen yaitu keterampilan membaca, menulis, menyimak dan berbicara. Satu di antara empat keterampilan berbahasa yang dapat menjadi sarana komunikasi serta alat dalam menyampaikan ide atau pendapat dalam kegiatan belajar mengajar adalah keterampilan menulis. Dengan adanya keterampilan menulis peserta didik mampu berkomunikasi serta menyampaikan informasi secara tulisan.

Berdasarkan hasil observasi dan wawancara peneliti dengan guru Bahasa Indonesia yang mengajar di sekolah tersebut menyimpulkan bahwa siswa kurang tertarik dalam pembelajaran menulis terkhusus menulis teks biografi. Sekolah SMA Parulian 1 Medan memiliki standar penilaian. Nilai KKM yang menjadi syarat kelulusan peserta didik adalah 70. Namun, pada kenyataan di sekolah tersebut hanya 50\% siswa yang mampu mencapai KKM dan 50\% lainnya tidak mencapai $\mathrm{KKM}$ dalam pembelajaran menulis teks biografi.

Berdasarkan permasalahan tersebut, pembelajaran menulis teks biografiperlu menggunakan model pembelajaran yang tepat. Salah satu model pembelajaran yang dapat digunakan dalam pembelajaran menulis teks biografiadalah dengan menggunakan model pembelajaran inkuiri.

Model pembelajaran inkuri adalah rangkaian kegiatan pembelajaran yang menekankan pada proses berpikir secara kritis dan analitis untuk mencari dan menemukan sendiri jawaban dari suatu masalah yang dipertanyakan. Model pembelajaran inkuiri dapat disimpulkan model yang dapat mendorong siswa untuk aktif dalam pembelajaran untuk memiliki pengalaman belajar dalam menemukan konsep-konsep materi berdasarkan masalah yang di ajukan."Berdasarkan latar belakang masalah di atas, masalah yang terkait dengan penelitian ini dapat diidentifikasi sebagai berikut: (1) Kurang berminatnya siswa dalam 
pembelajaran menulis teks biografi.

(2) Siswa masih kesulitan dalam mengungkapkan ide-ide,gagasan, dan pikirannya dalam bentuk lisan. (3)

Model yang digunakan guru masih belum sesuai dengan pembelajaran menulis teks biografi dan siswa kurang tertarik dalam pembelajaran menulis terkhusus menulis teks biografi. Berdasarkan identifikasi masalah tersebut, maka masalah penelitian ini dibatasi pada "Peningkatan Keterampilan Menulis Teks Biografi dengan Model Pembelajaran Inkuiri pada Siswa Kelas X SMA Parulian 1 Medan Tahun Pembelajaran 2018/2019”. Berdasarkan batasan masalah di atas, maka rumusan masalah dalam penelitian ini adalah.

Bagaimanakah kualitas proses pembelajaran keterampilan menulis teks biografi dengan menggunakan model pembelajaran inkuiri pada siswa kelas X SMA Parulian 1 Medan Tahun Pelajaran 2018/2019 ?. (2) Bagaimanakah kualitas hasil pembelajaran keterampilan menulis teks biografi dengan menggunakan model pembelajaran inkuiri pada siswa kelas X SMA Parulian 1
Medan Tahun Pelajaran 2018/2019 ?. (3) Apakah ada peningkatan hasil pembelajaran keterampilan menulis teks biografi dengan menggunakan model pembelajaran inkuiri pada siswa kelas $\mathrm{X}$ SMA Parulian 1 Medan Tahun Pelajaran 2018/2019 ?. Berdasarkan rumusan masalah tersebut, Penelitian ini bertujuan untuk mendeskripsikan keterampilan menulis teks biografisiswa kelas $\mathrm{X}$ SMA Parulian 1 Medanmenggunakan model pembelajaran Inkuiri.

Berdasarkan uraian yang dipaparkan, maka penulis tertarik melakukan penelitian yang berjudul "Peningkatan Keterampilan Menulis Teks Biografi dengan Model Pembelajaran Inkuiri pada Siswa Kelas X SMA Parulian 1 Medan Tahun Pembelajaran 2018/2019”.

\section{METODE PENELITIAN}

Sugiyono (2014:

mengatakan bahwa "Pendekatan penelitian merupakan cara ilmiah untuk mendapatkan data dengan tujuan dan kegunaan tertentu. Penelitian ini dilakukan dengan 
menggunakan metode Penelitian Tindakan Kelas (PTK). Pendekatan yang digunakan dalam penelitian adalah pendekatan deskriptif kualitatif dengan metode PTK yang merupakan jenis penelitian didasarkan atas data deskriptif dari setiap individu berupa sikap dan perilaku bisa diamatiselama proses pembelajaran berlangsung.

Penelitian ini dilaksanakan di SMA Parulian 1 Medan, Jalan Stadion Teladan Medan. Penelitian ini dilaksanakan pada semester genap tahun pelajaran 2018/2019. Subjek penelitian ini adalah siswa kelas $\mathrm{X}$ SMA Parulian 1 Medan Tahun Pelajaran 2018/2019 yang berjumlah 25 siswa.Dan objek dalam penelitian ini adalah upaya peningkatan keterampilan menulis teks biografi dengan model pembelajaran inkuiri pada sub pokok bahasan keterampilan menulis dikelas $\mathrm{X}$ SMA Parulian 1 Medan Tahun Pembelajaran 2018/2019.

Dalam penelitian ini data yang digunakan yaitu data siswa dan data yang diperoleh dari guru bahasa Indonesia yang mengajar di SMA
Parulian 1 Medan. Sumber data diperoleh dari tempat penelitian yakni di kelas X SMA Parulian 1 Medan yang berupa informasi dari guru dan siswa kelas $\mathrm{X}$ SMA Parulian 1 Medan melalui hasil wawancara, hasil tes belajar siswa pada pokok pembahasan menulis teks biografi mata pelajaran bahasa Indonesia melalui model pembelajara inkuiri.

Teknik pengumpilan data yang digunakan, yaitu wawancara, observasi, tes, dan dokumentasi.Indikator kinerja dalam penelitian ini apabila nilai kriteria ketuntasan minimal (KKM) keterampilan menulis teks biografi $>70$ dan nilai kriteria ketuntasan klasikal (KKK) $75 \%$ dari jumlah siswa. Artinya, jika siswa kelas $\mathrm{X}$ SMA Parulian 1 Medan sudah mencapai indikator kinerja tersebut maka kemampuan menulis teks biografi berhasil.

\section{HASIL DAN PEMBAHASAN}

Proses pembelajaran pada penelitian ini yang sudah dilaksanakan peneliti yang sudah menerapkan model pembelajaran 
inkuiri untuk memperbaiki keterampilan menulis teks biografi pada siswa kelas X SMA Parulian 1 Medan telah mendapatkan hasil penelitian dengan menyatakan bahwa keterampilan siswa menulis teks biografi yang telah diamati dapat meningkat. Hasil penelitian ini terlihat dari penilaian tes yang diberikan kepada siswa untuk dikerjakan disetiap tahap tahap kegiatan pembelajaran yang telah dilakukan penelitian yaitu siklus I, dan siklus II.

Pelaksanaan pembelajaran menulis teks biografi pada siklus I diberikan tes awal untuk mengetahui kemampuan awal pemahaman siswa terhadap materi pembelajaran menulis teks biografi dengan menerapkan model pembelajaran inkuiri.Adapun hasilnya, 12 siswa (48\%) yang lulusmendapatkan standar nilai KKM70. Sedangkan siswa yang belum lulus mendapatkan nilai 70 ada 13 siswa (52\%).

Dalam hal tersebut, peneliti pun melakukan perlakuan untuk memperbaiki situasi pembelajaran menulis teks biografi yang terjadi di kelas $\mathrm{X}$ dengan melakukan tindakan pembelajaran yaitu memperbaiki penerapan model pembelajaran inkuiri untuk menulis teks biografi yang dilaksanakan pada siklus II. Dari kegiatan pembelajaran tersebut sudah dilaksanakan dan hasil pelaksanaannya telah ditemukan jawabannya bahwa penerapan model pembelajaran inkuiri dapatmeningkatkan kemampuan menulis teks biografi pada siswa kelas XSMA Parulian 1 Medan. Adapun bukti data peningkatan nilai hasil pembelajaran menulis teks biografi siswa siklus I dan siklus II dari tes yang telah diberikan pada akhir proses pembelajaran di tiap siklusnya dapat dilihat dalam rangkuman hasil penilaian menulis teks biografi pada tabel 1 berikut. 
Tabel 1 Rekapitulasi Peningkatan Hasil Nilai Tes Keterampilan Menulis Teks Biografi Pada Siswa di Kelas X Pada Siklus I dan Siklus II

\begin{tabular}{c|c|c|c}
\hline $\begin{array}{c}\text { Rentang } \\
\text { Nilai }\end{array}$ & $\begin{array}{c}\text { Siklus } \\
\text { I }\end{array}$ & $\begin{array}{c}\text { Siklus } \\
\text { II }\end{array}$ & Ket \\
\hline $90-100$ & - & 6 & T \\
\hline $80-89$ & 3 & 8 & T \\
\hline $70-79$ & 9 & 8 & T \\
\hline $60-69$ & 8 & 3 & TT \\
\hline$<59$ & 5 & - & TT \\
\hline Nilai Tertinggi & $\mathbf{8 7}$ & $\mathbf{1 0 0}$ & - \\
\hline Nilai Terendah & $\mathbf{5 0}$ & $\mathbf{6 2}$ & - \\
\hline $\begin{array}{c}\text { Persentase } \\
\text { Ketuntasan Klasikal }\end{array}$ & $\mathbf{4 8 \%}$ & $\mathbf{8 8 \%}$ & - \\
\hline $\begin{array}{c}\text { Persentase Yang } \\
\text { Tidak Tuntas }\end{array}$ & $\mathbf{5 2 \%}$ & $\mathbf{1 2 \%}$ & - \\
\hline
\end{tabular}

Pada proses pembelajaran siklus I dan siklus II yang telah dilaksanakan dengan menerapkan model pembelajaran inkuiri perbaikan dari kondisi awal siswa agar dapat mencapai target KKM 70 dan KKK siswa $\geq 75 \%$. Adapun hasilnyapada kegiatan pembelajaran siklus I yang peneliti lakukan di kelas $\mathrm{X}$ siswa yang lulus mendapatkan standar KKM 70 hanya 12 siswa $48 \%$. Sedangkan siswa yang belum lulus mendapatkan nilai 70 ada 13 siswa $52 \%$. Pada proses siklus I indikator keberhasilan pada penilaian KKK siswa belum sesuai atau melampaui $\geq 75 \%$ sehingga dapat disimpulkan belum tercapai.

Melihat dari siklus I tersebut perlu dilakukan perbaikan dari permasalahan yang ada sehingga peneliti mengidentifikasi dan merencanakan perbaikannya dengan melakukan tindakan proses 
pembelajaran di siklus II agar pembelajaran menulis teks biografi siswa dapat meningkat sesuai nilai KKMpelajaran Bahasa Indonesia yaitu 70. Proses pembelajaran siklus II pun masih menggunakan model pembelajaran inkuiri. Adapun hasil penelitian yang peneliti peroleh nilai siswa di siklus II yang mendapatkan nilai 70 mencapai 22 siswa $88 \%$.
Sedangkan siswa yang belum lulus mendapatkan nilai 70 adalah 3 siswa $12 \%$.

Untuk memberikan gambaran yang jelas atas pencapaian hasil penelitian yang telah meningkat pada siklus I dan siklus II dari hasil tes dalam pembelajaran menyimpulkan teks hasil observasi dapat dilihat melalui diagram 1 sebagai berikut.

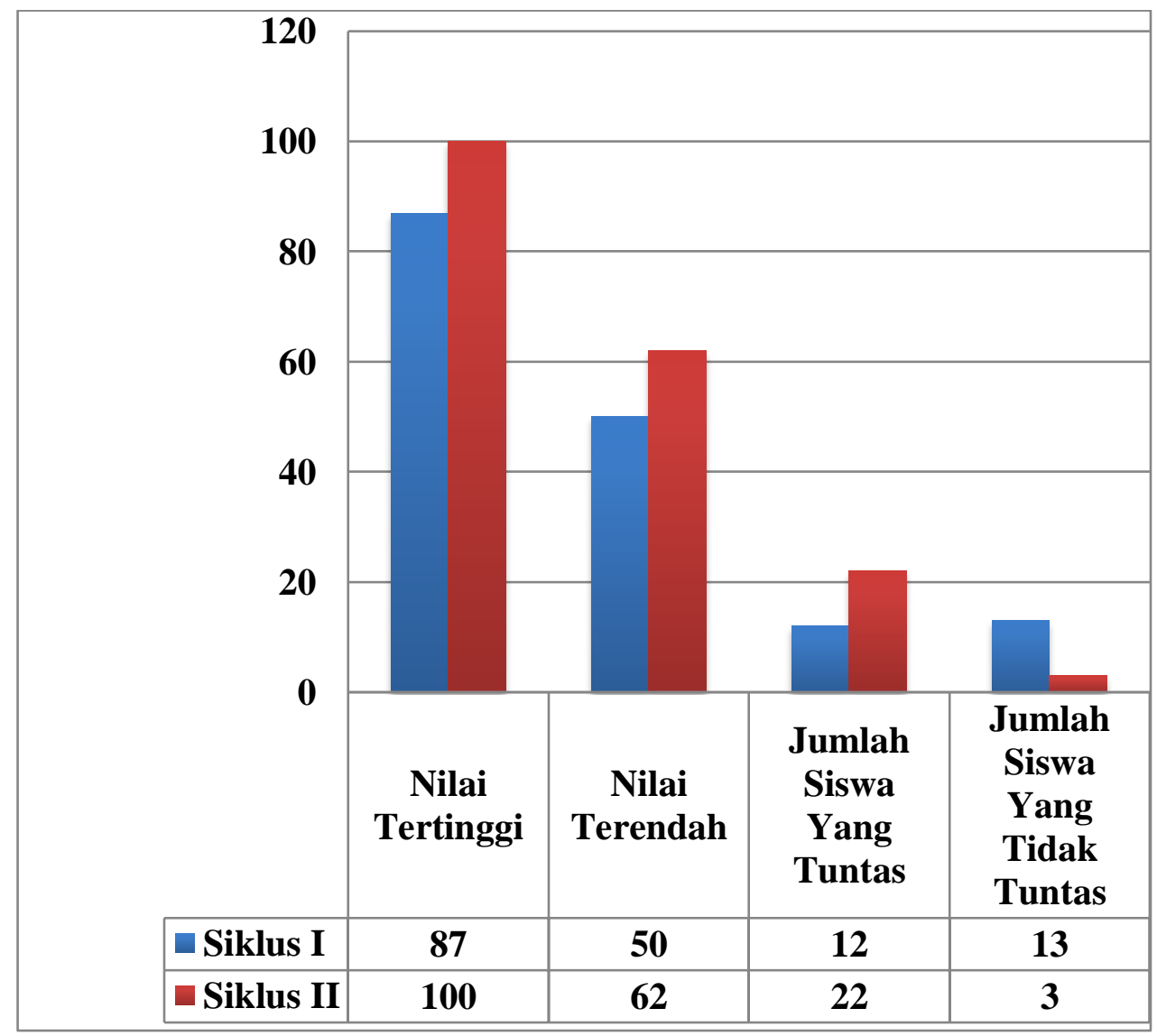




\section{Diagram 1 Peningkatan Hasil Nilai Tes Siklus I dan Siklus II Menulis Teks}

\section{Biografi pada SiswaKelas X SMA Parulian 1 Medan Tahun Pelajaran}

\section{8/2019}

$\begin{array}{ccccc}\text { Berdasarkan penelitian yang } & \text { mengondisikan } & \text { keadaan } \\ \text { telah dilakukan bahwa proses } & \text { pembelajaran yang } & \text { sedang }\end{array}$

pembelajaran yang menerapkan berlangsung di dalam kelas. Selama model pembelajaran inkuiri dapat meningkat kemampuan menulis teks biografi siswa kelas X. Oleh karena itu, model pembelajaran inkuiri pada mata pelajaran Bahasa Indonesia dapat berperan penting untuk meningkatkan keterampilan menulis teks biografi siswa apalagi model pembelajaran inkuiri mengajak siswa untuk berpikir kritis dan analitis. Artinya dalam pembelajaran menulis teks biografi dengan menggunakan model inkuiri di kelas $\mathrm{X}$ tersebut dapat meningkat kemampuan berpikir siswa, membuka wawasan siswa dengan mengaitkan materi pembelajaran dengan kehidupan sehari-hari, memberikan kesempatan kepada siswa dalam memberikan pendapatnya berdasarkan contoh teks biografi yang telah dibaca.

Model pembelajaran ini lebih menekankan keaktifan siswa dalam pembelajaran dan peneliti hanya sebagai fasilitator dalam kegiatan dikelas, siswa menulis teks biografi dan menentukan struktur biografi berdasarkan biografi tokoh yang mereka teliti. Langkah yang dilakukan dalam menulis teks biografi tokoh tersebut ialah, siswa merumuskan masalah yang terdapat dalam biografi tersebut, merumuskan hipotesis atau jawaban sementara, lalu siswa mengumpulkan data yang terdapat dalam teks biografi untuk memperkuat jawaban sementara yang telah ditentukan, lalu siswa menguji hipotesis berdasarkan data yang telah ditemukan agar jawaban tersebut diterima. Langkah-langkah tersebut dilakukan siswa dalam menulis teks biografi tokoh serta menemukan struktur teks biografi antara lain orientasi, peristiwa dan masalah yang dialami tokoh, reorientasi. Hal tersebut harus ditemukan siswa dalam biografi tokoh yang mereka teliti. sehingga hasil akhir yang diperoleh siswa 
mampu menulis teks biografi serta mampu menentukan struktur teks biografi melalui hasil kemampuan mereka sendiri dan dibuktikan melalui tes yang diberikan kepada siswa disetiap akhir siklus pembelajaran.

Dari keberhasilan dengan sudah meningkatnya keterampilan menulis teks biografi siswa kelas X, namun berdasarkan hasil pengamatan peneliti dan guru dari lembaran observasi kegiatan siswa pada siklus I dan siklus II terdapat beberapa aspek permasalahan yang telah diuraikan ditahap sebelumnya. Lalu direncanakanlah proses perlakuan perbaikan dalam suatu tindakan disetiap siklusnya. Bukan hanya itu, pada kegiatan pembelajaran siswa dengan model inkuiri di siklus I hanya 68 , nilai rata-rata keseluruhan siswa yang dapat dinyatakan memiliki tingkat penguasaan menulis teks biografi "rendah".

Hal ini karena masih banyak siswa yang tidak mengikuti intruksi peneliti untuk membaca atau mempelajari ulang materi pembelajaran yang telah disampaikan, dan masih banyak siswa yang kurang konsentrasi karena tidak terbiasa menggunakan model inkuiri pada proses pembelajaran, sehingga siswa masih ada siswa yang tidak berani memberikan hipotesis atau jawaban sementara terhadap menulis teks biografi.

Pada proses pembelajaran di siklus II yang masih menggunakan model inkuiri sudah mengalami peningkatan. Hasil pembelajaran mendapat nilai rata-rata keseluruhan siswa adalah 82 yang dapat dinyatakan tingkat kemampuan menulis teks biografi "tinggi". Hal ini karena sudah banyak siswa yang mau memberikan hipotesis atau jawaban sementara dan telah mengikuti intruksi dari peneliti dalam proses pembelajaran menulis teks biografi.

Namun dari semuanya itu, guru dan peneliti menyatakan bahwa proses pembelajaran menulis teks biografi dengan menggunakan model inkuiri pada siswa kelas X SMA Parulian 1 Medan sudah berjalan dengan baik dan lancar. Hasil penilaian di siklus I dan siklus II 
meningkat sesuai dengan Kriteria Ketuntasan Minimal $(\mathrm{KKM}) \geq 70$ dan nilai presentase Kriteria Ketuntasan Klasikal (KKK) siswa dengan nilaI $\geq 75 \%$. Dengan demikian, dapat disimpulkan bahwa berdasarkan rumusan masalah di Bab I dan hipotesis tindakan di Bab II telah dinyatakan dan dipaparkan pada hasil penelitian di Bab IV ini, dengan menggunakan model pembelajaran inkuiri dapat meningkatkan keterampilan siswa dalam menulis teks biografi siswa kelas X SMA Parulian 1 Medan. Dalam hal tersebut dapat membantu guru bidang studi Bahasa Indonesia untuk lebih aktif lagi dalam mengelola kelas.

\section{KESIMPULAN}

Peningkatan hasil pembelajaran menulis teks biografi dengan model pembelajaran inkuiri telah meningkat.Terbukti dari hasil penelitian nilai siklus I $48 \%$ dan terjadi peningkatan siklus II $88 \%$. Dan jumlah peningkatan yang di peroleh adalah $83 \%$.Oleh karena itu, model pembelajaran inkuiri pada bidang studi Bahasa Indonesia dengan sub pokok pembahasan materi pembelajaran menulis sangat berperan penting untuk meningkatkan kemampuan menulis teks biografi siswa dan mampu memberikan motivasi serta kesenangan siswa dalam proses pembelajaran kemampuan menulis teks biografi yang terkadang membuat siswa jenuh atau bosan sehingga siswa dapat lebih aktif dan lebih bersemangat dalam proses pembelajaran kemampuan menulis teks biografi di kelas XSMAParulian 1 Medan.

\section{DAFTAR PUSTAKA}

Arikunto, Surhasimi. 2006, Prosedur Penelitian Suatu Pendekatan Praktik. Jakarta PT. Rineka Cipta.

Aqib, Zainal. 2011. Pendidikan Karakter Membangun Perilaku Positif Anak Bangsa. Bandung. Yrama Widya.

Dalman. 2011. Keterampilan Menulis. Bandar Lampung: PT Raja Grafindo Persada. 
Hamdayana, Jumanta. 2014. Model dan Metode Pembelajaran. Jakarta.

Kurniasih. 2015. Ragam Pengembangan Model Pembelajaran. CV. Solusi Distribusi: Kata Pena.

Mahsun. 2014. "Keterampilan Menulis Teks Biografi Siswa Kelas VIII SMP Negeri 20 Padang Menggunakan Strategi Pembelaajaran Aktif Tipe Imformation Search (Mencari Informasi)". Skripsi STKIP PGRI. PGRI Sumatera Barat: tidak diterbitkan

Rusman. 2016. Model-Model Pembelajaran. Jakarta: PT Raja Grafindo Persada.

Sudjana. 2005. Metoda Statistika. Bandung: Tarsito.

Sugiyono. 2017. Metode Penelitian Kuantitatif, Kualitatif, dan $R \& D$. Bandung, AlfaBeta.

Tarigan, H. G. 1986, Keterampilan Menulis dan Berbahasa, Bandung: Angkasa Jaya. 